\title{
DAYA TERIMA KUE PIA DENGAN SUBSTITUSI TEPUNG TIRAM (Crassostrea gigas) PADA BALITA STUNTING
}

\author{
Mustamin $^{1}$, Hijrah Asikin ${ }^{1}$, Mursydati ${ }^{2}$ \\ ${ }^{1}$ Jurusan Gizi, Politeknik Kesehatan Kemenkes, Makassar \\ ${ }^{2}$ Alumni Prodi Sarjana Terapan Gizi dan Dietetik, Politeknik Kesehatan Kemenkes, Makassar
}

Korespondensi : Mursydati@poltekkes-mks.ac.id 085342394206

\begin{abstract}
Stunting problems entering to one of development priority programs in 2015-2019 health.One effort to prevent potential stunting is by using local food which is easily reached by way oysters and use.Processing flour oysters in the shape of pie pia could be any an alternative as an effort to handle malnutrition considering in terms of nutrients, and the benefits for health. This research aims to find out the accept boochie with the substitution of flour oysters in toddlers stunting. The research is pre experimental research and design study that used design group one shot. Resources $i$ judged based on the organoleptik against 30. panelistsThen analyzed using kruskal-wallis, test about the further mann whitney, the results of the analysis resources received best nutrients. The research results show of panelis best - to pia cake flour oysters with the substitution of 5\%. The panel like aspects think 56,67\%, the aspect of the scent of 50,00\%, the aspect of texture $63,33 \%$, the aspect of color 96,67\%. Did research on the save pia.
\end{abstract}

Keywords : Pia cake, Stunting, Oysters

\section{PENDAHULUAN}

Masalah stunting dianggap sebagai masalah kesehatan dan harus segera ditangani, jika memiliki prevalensi $\geq 20 \%$, prevalensi stunting di Indonesia tahun $2018(30,8 \%)$ menurun jika dibandingkan pada tahun 2007 (36,8\%), 2010 (35,6\%) dan 2013 (37,3\%), prevalensi masih lebih tinggi dari $20 \%$ sehingga masalah stunting masuk ke dalam salah satu program prioritas pembangunan kesehatan dalam tahun 2015-2019. Prevalensi stunting di Indonesia relatif tinggi jika dibandingkan dengan negara berkembang lainnya, seperti Myanmar, Vietnam, Malaysia, Thailand dan Singapura. (Riskesdas 2007, 2010, 2013, 2018, Kemenkes RI).

Data Pemantauan Status Gizi (PSG) 2017 menunjukkan prevalensi anak stunting di Provinsi Sulawesi Selatan yaitu $15,7 \%$ dan sangat pendek 6,1\% (Kementerian Kesehatan RI, 2017). Dampak stunting tidak hanya dirasakan oleh individu yang mengalaminya, tetapi juga berdampak terhadap roda perekonomian dan pembangunan bangsa. Hal ini karena sumber daya manusia stunting memiliki kualitas lebih rendah dibandingkan dengan sumber daya manusia normal (Zilda \& Sudiarti, 2013).

Penelitian terbaru menyatakan bahwa stunting terjadi akibat defisiensi zat gizi mikro dalam waktu lama, di antaranya adalah defisiensi seng. Defisiensi seng pada anak terjadi karena konsumsi dietnya rendah kandungan seng. Seng juga merupakan mikromineral esensial sebagai kofaktor lebih dari 100 metaloenzim yang 
berperan penting dalam regenerasi sel, metabolisme, pertumbuhan dan perbaikan jaringan (Osredkar, 2011).

Salah satu upaya untuk mencegah terjadinya stunting adalah dengan memanfaatkan potensi pangan lokal yang mudah dijangkau oleh seluruh lapisan masyarakat. Salah satu potensi pangan lokal yang ada di masyarakat belum dimanfaatkan secara optimal yaitu dengan cara memanfaatkan tiram. Tiram tergolong jenis kerang yang kaya dengan kandungan protein, besi, magnesium, kalsium, seng, dll (Octavina dkk, 2014).

Tiram seperti hidangan laut lainnya tinggi akan kandungan protein, seng, omega-3 dan rendah kolesterol. Para ahli gizi mengatakan bahwa tiram mengandung banyak asam amino tirosin, yang membantu meningkatkan suasana hati (mood) dan mengatur kadar stres. Tiram mengandung seng lebih banyak dari pada jenis makanan lain. Kehadiran seng dalam tubuh akan sangat memengaruhi fungsi kekebalan tubuh, sehingga berperan penting dalam pencegahan infeksi oleh berbagai jenis bakteri patogen. Akibat lain dari kekurangan seng adalah meningkatkan risiko diare dan infeksi saluran nafas (Sumedi \& Sandjaja, 2015).

Kue pia adalah makanan yang terbuat dari campuran kacang hijau dengan gula yang dibungkus dengan tepung lalu dipanggang. Kue pia termasuk makanan yang popular dari Cina atau Tionghoa. Kue pia pada umumnya dibuat dengan isian berbahan kacang hijau, namun dengan perkembangan jaman yang semakin pesat khususnya dibidang kuliner, dewasa ini bakpia dapat dibuat dari berbagai macam bahan seperti ketan hitam, coklat, keju dan ubi jalar ungu.(Puspawati dkk, 2016).

Pengolahan tepung tiram dalam bentuk kue pia bisa jadi salah satu alternatif dalam upaya mengatasi malnutrisi dengan mempertimbangkan dari segi zat gizi, manfaatnya bagi kesehatan dan daya terima. Kue pia, biskuit atau makanan jajanan lainya merupakan salah satu faktor yang penting bagi pertumbuhan anak, karena menyumbangkan energi dan zat gizi yang diperlukan anak (Murphy dkk, 2007).

Zaman sekarang anak-anak kurang tertarik dengan makanan laut seperti ikanikan dan kerang-kerangan, sehingga peneliti membuat kue pia dengan substitusi tepung tiram sebagai alternatif agar anakanak balita tertarik untuk mengonsumsinya. Tingginya kandungan gizi yang terdapat dalam tiram terutama protein dan seng maka peneliti melakukan penelitian tentang daya terima kue pia dengan substitusi tepung tiram (Crassostrea gigas) pada balita stunting.

\section{METODE}

\section{Desain, tempat dan waktu}

Desain penelitian yang digunakan adalah desain One Shoot Group. Penelitian ini dilakukan di Laboratorium Teknologi Pangan Jurusan Gizi Politeknik Kesehatan Kementerian Kesehatan Makassar. Penelitian telah dilakukan pada tanggal 25 bulan April 2019.

\section{Bahan dan alat}

Bahan yang digunakan untuk pembuatan tepung tiram yaitu tiram segar, jeruk nipis/cuka, es batu, garam dan air. Bahan-bahan yang digunakan untuk pembuatan kue pia yaitu kacang hijau, tepung terigu, gula pasir, minyak kelapa dan vanili.

Alat yang digunakan untuk pembuatan tepung tiram yaitu oven, blender, talenan, pisau, sendok, ayakan (60 mesh), panci kukusan, timbangan makanan dan baskom. Alat yang digunakan dalam pembuatan kue pia ialah; kompor, oven, loyang, wajan, sutil, sendok, baskom, gelas ukur dan timbangan makanan.

\section{Langkah-Langkah Penelitian}

1) Pembuatan Tepung Tiram sebagai berikut

Proses pembuatan tepung tiram dimulai bahan baku daging tiram 
dipisahkan dari cangkangnya, dibersihkan dari kotoran seperti ranting, pasir dan lain-lain agar tidak mengganggu proses pembuatan tepung dan menurunkan kualitas tepung tiram. Daging tiram yang telah dibersihkan diberi perasan air jeruk atau cuka untuk mengurangi aroma dari tiram, kemudian direndam dalam air es dan garam selama kurang lebih 30 menit untuk mengurangi gas dan lemak yang ada pada daging tiram, lalu ditiriskan. Daging tiram dikukus selama kurang lebih 30 menit. Setelah dikukus, daging tiram dibiarkan diudara terbuka. Selagi daging tiram masih dalam keadaan panas, sebaiknya daging tiram ditekan agar lemak yang terkandung dapat dipisahkan dengan cairan daging tiram. Ampas daging tiram (bahan padat hasil penekanan) selanjutnya dijemur dibawah sinar matahari sampai kering. Pengeringan dapat juga dilakukan dengan cara mengalirkan ampas daging tiram tersebut ke dalam alat yang mengandung udara panas atau menggunakan oven. Ampas daging yang telah kering segera digiling dan diayak (60 mesh) untuk mendapatkan tepung daging tiram yang halus.

2) Proses pembuatan Kue Pia dengan Substitusi Tepung Tiram

Tahap pertama yang dilakukan adalah persiapan bahan baku tepung terigu dan kacang hijau. Selanjutnya pengukusan kacang hijau hingga matang dan hancur, Kacang hijau yang telah hancur dilakukan pengadonan selama 1 jam dengan penambahan gula dan minyak kelapa serta ditambahkan tepung tiram dan didinginkan. Setelah pengolahan isi kue pia, maka selanjutnya adalah pembuatan kulit kue pia yaitu tepung terigu, minyak kelapa dan air di campurkan hingga kalis, kemudian dilakukan pelembaran (rolling) kulit kue pia untuk mengeluarkan gas yang ada di dalam adonan dan melembutkan tekstur adonan. Kemudian adonan kulit pia diisi dengan isian kacang hijau dibentuk bulat melempeng, selanjutnya dilakukan pemanggangan dengan menggunakan oven hingga terjadi perubahan warna kecoklatan menandakan kue pia telah matang.

Pengolahan dan analisis data

Data yang dikumpulkan diolah menggunakan program Microsoft Excel. Selanjutnya analisa data daya terima menggunakan uji krusskal-wallis, kemudian dilanjutkan dengan uji Mann Whitney dengan menggunakan alfa 95\%. Data yang telah diolah dianalisis, selanjutnya disajikan dalam bentuk tabel disertai penjelasan dalam bentuk narasi.

\section{HASIL}

Tabel 1

Distribusi Hasil Daya Terima Kue Pia Tepung Tiram Berdasarkan Aspek Warna

\begin{tabular}{|c|c|c|c|c|c|c|c|}
\hline \multirow{3}{*}{$\begin{array}{l}\text { Konsentrasi } \\
\text { Kue Pia }\end{array}$} & \multicolumn{4}{|c|}{$\begin{array}{l}\text { Tingkat kesukaan aspek } \\
\text { warna }\end{array}$} & \multirow{2}{*}{\multicolumn{2}{|c|}{ Total }} & \multirow{3}{*}{$p^{1)}$} \\
\hline & \multicolumn{2}{|c|}{ Suka } & \multicolumn{2}{|c|}{ Tidak suka } & & & \\
\hline & $\mathrm{n}$ & $\%$ & $\mathrm{n}$ & $\%$ & $\mathrm{n}$ & $\%$ & \\
\hline $0 \%$ & 26 & 86,67 & 4 & 13,33 & 30 & 100 & \multirow{4}{*}{0,030} \\
\hline $5 \%$ & 29 & 96,67 & 1 & 3,33 & 30 & 100 & \\
\hline $10 \%$ & 22 & 73,33 & 8 & 26,67 & 30 & 100 & \\
\hline $15 \%$ & 23 & 76,67 & 7 & 23,33 & 30 & 100 & \\
\hline
\end{tabular}


Tabel 1 menunjukkan bahwa konsentrasi substitusi tepung tiram yang banyak disukai dari aspek warna yaitu konsentrasi 5\% sebanyak 29 panelis $(96,67 \%)$. Hasil uji KruskalWallis menunjukkan hasil $\mathrm{p}(0,030)<$ 0,05 , terdapat perbedaan dari aspek warna yang signifikan di beberapa konsentrasi kue pia dengan substitusi tepung tiram, sehingga dilakukan uji lanjut Mann Whitney, konsentrasi yang berbeda adalah konsentrasi $0 \%$ dengan $10 \%$ dan konsentrasi $5 \%$ dengan $10 \%$.

Tabel 2

Distribusi Hasil Daya Terima Kue Pia Tepung Tiram

Berdasarkan Aspek Tekstur

\begin{tabular}{cccccccc}
\hline \multirow{2}{*}{$\begin{array}{c}\text { Konsentrasi } \\
\text { Kue Pia }\end{array}$} & \multicolumn{3}{c}{ Tingkat kesukaan aspek warna } & \multicolumn{2}{c}{ Total } & \multirow{2}{*}{$p^{1)}$} \\
\cline { 2 - 6 } & $\mathrm{n}$ & $\%$ & $\mathrm{n}$ & $\%$ & $\mathrm{n}$ & $\%$ & \\
\hline $0 \%$ & 24 & 80,00 & 6 & 20,00 & 30 & 100 & \\
$5 \%$ & 19 & 63,33 & 11 & 36,67 & 30 & 100 & 0,000 \\
$10 \%$ & 10 & 33,33 & 20 & 66,67 & 30 & 100 & \\
$15 \%$ & 10 & 33,33 & 20 & 66,67 & 30 & 100 & \\
\hline
\end{tabular}

Tabel 2 menunjukkan bahwa konsentrasi substitusi tepung tiram yang banyak disukai dari aspek tekstur yaitu konsentrasi 0\% sebanyak 24 panelis $\quad(80,00 \%)$, menyusul konsentrasi $5 \%$ sebanyak 19 panelis (63,33\%). Hasil uji Kruskal-Wallis menunjukkan hasil $\mathrm{p}(0,000)<0,05$, terdapat perbedaan dari aspek tekstur yang signifikan di setiap konsentrasi kue pia dengan substitusi tepung tiram, sehingga dilakukan uji lanjut Mann Whitney, konsentrasi berbeda adalah konsentrasi $0 \%$ dengan konsentrasi 10\%, konsentrasi $0 \%$ dengan $15 \%$, konsentrasi $5 \%$ dengan konsentrasi $10 \%$ dan konsentrasi $5 \%$ dengan konsentrasi $15 \%$.

Tabel 3

Distribusi Hasil Daya Terima Kue Pia Tepung Tiram

Berdasarkan Aspek Aroma

\begin{tabular}{cccccccc}
\hline \hline \multirow{2}{*}{$\begin{array}{c}\text { Konsentrasi } \\
\text { Kue Pia }\end{array}$} & \multicolumn{3}{c}{ Tingkat kesukaan aspek warna } & \multicolumn{2}{c}{ Total } & \multirow{2}{*}{$p^{1)}$} \\
\cline { 2 - 6 } & \multicolumn{2}{c}{ Suka } & \multicolumn{2}{c}{ Tidak suka } & & & \\
& $\mathrm{n}$ & $\%$ & $\mathrm{n}$ & $\%$ & $\mathrm{n}$ & $\%$ & \\
\hline $0 \%$ & 30 & 100,00 & 0 & 0,00 & 30 & 100 & \\
$5 \%$ & 15 & 50,00 & 15 & 50,00 & 30 & 100 & 0 \\
$10 \%$ & 9 & 30,00 & 21 & 70,00 & 30 & 100 & \\
$15 \%$ & 10 & 33,33 & 20 & 66,67 & 30 & 100 & \\
\hline
\end{tabular}

Tabel 3 menunjukkan bahwa konsentrasi substitusi tepung tiram yang banyak disukai dari aspek aroma yaitu konsentrasi $0 \%$ sebanyak 30 panelis $\quad(100,00 \%), \quad$ menyusul konsentrasi $5 \%$ sebanyak 15 panelis (50,00\%). Hasil uji Kruskal-Wallis menunjukkan hasil $\mathrm{p}(0,000)<0,05$, 
terdapat perbedaan dari aspek aroma yang signifikan di beberapa konsentrasi kue pia dengan substitusi tepung tiram. sehingga dilakukan uji lanjut Mann Whitney, konsentrasi berbeda adalah konsentrasi $0 \%$ dengan konsentrasi 5\%, konsentrasi $0 \%$ dengan $10 \%$ dan konsentrasi $0 \%$ dengan konsentrasi $15 \%$.

Tabel 4

Distribusi Hasil Daya Terima Kue Pia Tepung Tiram

Berdasarkan Aspek Rasa

\begin{tabular}{|c|c|c|c|c|c|c|c|}
\hline \multirow{3}{*}{$\begin{array}{c}\text { Konsentrasi } \\
\text { Kue Pia }\end{array}$} & \multicolumn{4}{|c|}{ Tingkat kesukaan aspek warna } & \multirow{2}{*}{\multicolumn{2}{|c|}{ Total }} & \multirow{3}{*}{$p^{1)}$} \\
\hline & \multicolumn{2}{|c|}{ Suka } & \multicolumn{2}{|c|}{ Tidak suka } & & & \\
\hline & $\mathrm{n}$ & $\%$ & $\mathrm{n}$ & $\%$ & $n$ & $\%$ & \\
\hline $0 \%$ & 30 & 100,00 & 0 & 0,00 & 30 & 100 & \multirow{4}{*}{0,000} \\
\hline $5 \%$ & 17 & 56,67 & 13 & 43,33 & 30 & 100 & \\
\hline $10 \%$ & 8 & 26,67 & 22 & 73,33 & 30 & 100 & \\
\hline $15 \%$ & 8 & 26,67 & 22 & 73,33 & 30 & 100 & \\
\hline
\end{tabular}

Tabel 4 menunjukkan bahwa konsentrasi substitusi tepung tiram yang banyak disukai dari aspek rasa yaitu konsentrasi 0\% sebanyak 30 panelis $(100,00 \%)$, menyusul konsentrasi 5\% sebanyak 17 panelis (56,67\%). Hasil uji Kruskal-Wallis menunjukkan hasil $\mathrm{p}(0,000)<0,05$, terdapat perbedaan dari aspek rasa yang signifikan di setiap konsentrasi kue pia dengan substitusi tepung tiram. sehingga dilakukan uji lanjut Mann Whitney, konsentrasi berbeda adalah konsentrasi $0 \%$ dengan konsentrasi 5\%, konsentrasi 0\% dengan 10\%, konsentrasi $0 \%$ dengan konsentrasi $15 \%$, konsentrasi $5 \%$ dengan konsentrasi $10 \%$ dan konsentrasi $5 \%$ dengan konsentrasi $15 \%$.

\section{PEMBAHASAN}

Warna merupakan salah satu faktor yang sangat penting dalam penerimaan atau penolakan suatu produk karena kesan pertama yang dilihat panelis (Fitri, dkk, 2017). Hasil penelitian uji organoleptik bahwa kue pia dengan substitusi tepung tiram konsentrasi 5\% tingkat penerimaan lebih tinggi dibandingkan kue pia dengan substitusi tepung tiram konsentrasi $0 \%$, $10 \%, 15 \%$. Namun tidak ada perbedaan yang signifikan terhadap daya terima panelis sehingga masih sulit dibandingkan dengan kue pia dengan substitusi tepung tiram konsentrasi lainnya. Sejalan dengan penelitian yang dilakukan oleh (Hestin dan Ninik, 2013) menunjukkan bahwa nilai $\mathrm{p}<0,05(0,506)$ yang berarti tidak ada perbedaan nyata kesukaan panelis terhadap warna cookies yang dihasilkan.

Namun dalam hal ini, hasil uji Mann Whitney yang berbeda dari aspek warna pada kue pia, ialah kue pia dengan substitusi tepung tiram konsentrasi 0\% dengan $10 \%$, dan kue pia dengan substitusi tepung tiram konsentrasi $5 \%$ dan $10 \%$ dari segi aspek warna $\mathrm{p}<(0.05)$, sedangkan kue pia dengan substitusi tepung tiram konsentrasi lainnya tidak ada perbedaan dari segi aspek warna $\mathrm{p}>(0.05)$.

Hal ini sesuai juga dengan bahan adonan kulit kue pia yang dibuat untuk setiap konsentrasi sama, selain itu perbedaan warna kulit berbeda dari setiap kue pia juga dipengaruhi pada proses pemanggangan kue. Bahan-bahan tersebut akan mengalami pencoklatan apabila 
mengalami proses pemanggangan karena mengandung senyawa yang dapat menyebabkan reaksi browning non enzimatis. Asam amino yang berada pada bahan berikatan dengan gugus gula pereduksi seperti fruktosa, laktosa dan maltosa dalam suasana panas menyebabkan warna bahan makanan menjadi kecoklatan.

Hal ini sejalan dengan penelitian yang dilakukan oleh Nadimin, dkk (2018), Hasil analisis statistik menunjukkan tidak terdapat pengaruh yang signifikan pada konsentrasi tepung ikan gabus terhadap warna produk jajanan lokal bolu, bangke sagu dan putri salju. Warna produk jajanan yang dihasilkan sebagian besar adalah warna coklat. Hal ini sesuai dengan komposisi bahan dasar dalam pembuatan jajanan tersebut. Bahan dasar yang banyak digunakan pada pembuatan jajanan lokal adalah tepung sagu, tepung terigu dan gula sehingga dapat menyebabkan terjadinya reaksi maillard.

Reaksi Maillard merupakan pencoklatan (browning) makanan pada pemanasan atau pada penyimpanan, biasanya diakibatkan oleh reaksi kimia antara gula reduksi, terutama D- glukosa, dengan asam amino bebas atau gugus amino bebas dari suatu asam amino yang merupakan bagian dari suatu rantai protein. Kecepatan reaksi Maillard dapat dipengaruhi oleh suhu dan lama pemanasan (Winarno,1997).

Berbeda dengan hasil penelitian yang dilakukan Fitri (2017) berdasarkan uji Kruskall Wallis diketahui bahwa nilai $p=0,000(\rho<0,05)$ yang menunjukkan ada pengaruh substitusi tepung daging ikan kembung terhadap warna biskuit ikan kembung. Biskuit ikan kembung substitusi $0 \%$ tidak berbeda dengan biskuit ikan kembung yang disubstitusi $5 \%$ tetapi berbeda dengan biskuit yang disubstitusi $10 \%$ dan $15 \%$. Biskuit ikan kembung substitusi $5 \%$ berbeda dengan biskuit ikan kembung yang disubstitusi $10 \%$ dan $15 \%$.
Biskuit ikan kembung yang disubstitusi $10 \%$ berbeda dengan $15 \%$. Semakin banyak substitusi tepung daging ikan kembung yang ditambahkan ke dalam formulasi biskuit maka warna biskuit akan menjadi lebih gelap.

Tekstur merupakan gambaran yang memperlihatkan kekuatan suatu produk makanan dipengaruhi oleh bahan dasar dan perlakuan selama proses pegolahan, dimana tekstur memengaruhi cita rasa yang ditimbulkan oleh bahan tersebut (Winarno,2004).

Tekstur suatu produk makanan dapat diketahui dengan mengunyah makanan. Hasil penelitian menunjukkan bahwa tekstur tekstur yang paling disukai panelis adalah kue pia original (konsentrasi $0 \%$ ) berlanjut kue pia konsentrasi $5 \%$, semakin tinggi substitusi tepung tiram pada kue pia maka semakin rendah daya terima panelis terhadap tekstur kue pia. Hasil uji kruskal wallis menunjukkan nilai $\mathrm{p}>0,05$ yang berarti ada perbedaan kesukaan panelis terhadap tekstur pada setiap konsentrasi kue pia.

Hal ini sejalan dengan penelitian yang dilakukan oleh Listiana (2016) bahwa substitusi tepung ikan tongkol memberikan pengaruh yang nyata terhadap daya terima tekstur biskuit. Semakin tinggi substitusi tepung ikan tongkol menyebabkan semakin rendah daya terima terhadap tekstur. Salah satu yang mempengaruhi tekstur adalah kandungan gluten pada bahan pembuatan biskuit.

Adapun faktor-faktor yang mempengaruhi tekstur biskuit ditentukan oleh bahan-bahan yang digunakan yaitu kadar protein tepung terigu. Semakin tinggi kadar protein pada tepung terigu maka akan mempengaruhi tekstur pada biskuit menjadi lebih keras serta jumlah lemak yang digunakan akan mempengaruhi tekstur biskuit menjadi lebih lembut (Dahrul dkk, 2008). Semakin tinggi substitusi tepung tiram 
menyebabkan semakin berkurangnya proporsi gluten yang berperan penting dalam membentuk tekstur kue pia. Tepung tiram tidak mengandung gluten yang merupakan komponen sangat penting dalam proses adonan yang akan mempengaruhi tekstur kue pia.

Aroma adalah bau yang ditimbulkan oleh rangsangan kimia yang tercium oleh syarat-syarat olfaktori yang berbeda dalam rongga hidung ketika makanan masuk kedalam mulut (Winarno,2004). Aroma yang dihasilkan oleh makanan banyak menentukan kelezatan bahan pangan tersebut.

Hasil penelitian kue pia dengan substitusi tepung tiram yang sangat disukai oleh panelis yaitu konsentrasi $0 \%$ dengan jumlah panelis yang suka 30 orang panelis dan yang kurang disukai yaitu konsentrasi 10\%. Penambahan tepung tiram menghasilkan aroma amis pada kue pia. Aroma dari suatu produk terdeteksi ketika zat yang mudah menguap (volatil) dari produk tersebut terhirup diterima oelh sistem penciuman. Hal ini menunjukkan bahwa adanya penambahan tepung tiram pada kue pia akan menurunkan penerimaan panelis terhadap aroma kue pia.

Hal ini sejalan dengan penelitian yang dilakukan oleh Fitri (2017) menyatakan bahwa ada pengaruh substitusi tepung daging ikan kembung terhadap aroma biskuit ikan kembung.

Rasa merupakan aspek penting dalam menilai suatu makanan tertentu dengan menggunakan panca indera pengecap dan merupakan hal kedua setelah penampilan makanan dalam membentuk pilihan terhadap makanan dan orang-orang menilai cita rasa sebagai alasan utama untuk memilih makanan tertentu, setiap orang memiliki kepekaan berbeda-beda dalam menilai suatu produk/makanan (Fellows,2014).

Aspek rasa dari hasil penelitian kue pia dengan substitusi tepung tiram yang sangat disukai oleh panelis yaitu konsentrasi $0 \%$ selanjutnya kue pia konsentrasi $5 \%$ dan yang kurang disukai yaitu konsentrasi $10 \%$ dan $15 \%$

Diantara tiga konsentrasi $5 \%, 10 \%$ dan $15 \%$ menunjukkan bahwa panelis lebih menerima terhadap konsentrasi 5\%, hal ini dikarenakan substitusi tepung tiram tidak terlalu tinggi. Rasa kue pia dengan dengan substitusi tepung tiram memiliki rasa khas, berbeda dengan kue pia pada umumnya rasanya sudah biasa dikalangan masyarakat yaitu rasa manis sehingga jika ditambahkan tepung tiram dengan konsentrasi yang semakin tinggi membuat kue pia memiliki rasa khas tiram dan memengaruhi daya terima kue pia.

Sejalan dengan penelitian Nadimin (2017) menunjukkan ada pengaruh penambahan tepung ikan gabus terhadap daya terima konsumen pada bangke sagu pada aspek rasa. Pengguna tepung ikan gabus dalam jumlah yang banyak cenderung menurunkan daya terima konsumen. Penelitian yang dilakukan Nadimin, dkk (2017) menyatakan bahwa konsentrasi tepung kerang untuk cemilan lokal tidak boleh melebihi $10 \%$ untuk mempertahankan kepuasan yang diterima balita.

Jadi dari hasil penelitian-penelitian sebelumnya ambang batas konsentrasi tepung tiram untuk aspek rasa yang dapat diterima panelis adalah 5\%.

Tingkat kesukaan secara keseluruhan dari aspek warna yang palin disukai adalah konsentrasi 5\%. Sedangkan dilihat dari aspek tekstur, aroma dan rasa kue pia dengan substitusi tepung tiram yang memiliki penerimaan paling tinggi adalah konsentrasi $0 \%$ atau original tanpa penambahan substitusi, kemudian secara berturut-turut adalah konsentrasi 5\%, konsentrasi $15 \%$, lalu konsentrasi $10 \%$. Total skor konsentrasi $5 \%$ lebih rendah dibandingkan dengan original (konsentrasi $0 \%$ ).

\section{KESIMPULAN}


Pembuatan kue pia dengan substitusi tepung tiram, semakin tinggi konsentrasi tepung tiram yang ditambahkan kedalam kue pia akan memengaruhi dari aspek warna, tekstur, aroma dan rasa. Daya terima kue pia dari aspek warna yang paling tinggi yaitu konsentrasi 5\%. Daya terima kue pia dari aspek tekstur yang paling tinggi yaitu konsentrasi 0\% menyusul konsentrasi 5\%. Daya terima kue pia dari aspek aroma yang paling tinggi yaitu konsentrasi $0 \%$ menyusul konsentrasi 5\%. Daya terima kue pia dari aspek rasa yang paling tinggi yaitu konsentrasi $0 \%$ menyusul konsentrasi $5 \%$.

\section{SARAN}

Saran peneliti selanjutnya sebaiknya dilakukan penelitian mengenai masa simpan kue pia dengan substitusi tepung tiram.

\section{DAFTAR PUSTAKA}

Dahrul, S dan Anggita, WR. (2008). Kajian Formulasi Cookies Ubi Jalar (Ipmoea batatas L.) dengan Karakteristik Tekstur Menyerupai Cookies Keladi. Departemen Ilmu dan Teknologi Pangan. IPB. Bogor

Damayanti, R. A., Muniroh, L., \& Farapti. (2016). Perbedaan tingkat kecukupan zat gizi dan riwayat pemberian ASI eksklusif pada balita stunting dan non stunting. Media Gizi Indonesia, 11(1).

Fellows, P. J. (2014). TeknologI Pengolahan Pangan Prinsip dari Praktik Jakarta. Penerbit Buku Kedokteran EGC.

Fitri. N dan Purwani. E. (2017) Pengaruh Substitusi Tepung Ikan Kembung (Rastrelliger Brachysoma) Terhadap Kadar Protein dan Daya Terima Biskuit. Universitas Muhammadiya Surakarta.

Hestin, R, dan Ninik, R. (2013). Pengaruh Substitusi Tepung Tempe dan Ikan Teri Nasi (Stolephorus sp) Terhadap Kandungan Protein, Kalsium, dan
Organoleptik Cookies. Semarang; Program studi Ilmu Gizi Fakultas Kedokteran Universitas Diponegoro

Kementerian Kesehatan RI. (2017). Buku Saku Pemantauan Status Gizi Tahun 2017, 140. Jakarta Selatan: Direktorat Gizi Masyarakat.

Kementerian Kesehatan RI. (2010). Riset Kesehatan Dasar, RISKESDAS 2010. Jakarta: Badan Penelitian pengembangan kesehatan kementerian kesehatan RI.

Kementerian Kesehatan RI. (2013). Riset Kesehatan Dasar, RISKESDAS 2013. Jakarta: Badan Penelitian pengembangan kesehatan kementerian kesehatan RI.

Kementerian Kesehatan RI. (2018). Riset Kesehatan Dasar, RISKESDAS 2018. Jakarta: Badan Penelitian pengembangan kesehatan kementerian kesehatan RI.

Listina L. (2016). Pengaruh substitusi tepung ikan tongkol terhadap kadar protein, kekerasan dan saya terima biskuit. Surakarta. Universitas Muhammadiyah Surakarta.

Murphy, S. P., Gewa, C., Grillenberger, M., Bwibo, N. O., \& Neumann, C. G. (2007). Designing snacks to address micronutrient deficiencies in rural Kenyan schoolchildren. J Nutr, 137, 1093-1096. https://doi.org/137/4/1093 [pii]

Nadimin. (2017). Pengaruh Substitusi Tepung Ikan Gabus Terhadap Daya Terima Bangke Sagu. Makassar. Media Gizi Pangan Vol. XXIV, Edisi 2, Tahun 2017.

Osredkar, J. (2011). Copper and Zinc, Biological Role and Significance of Copper/Zinc Imbalance. Journal of Clinical Toxicology, s3(1), 1-18. https://doi.org/10.4172/2161-0495.S3001

Octavina C. (2014). Aspek pemanfaatan sumberdaya tiram daging (Ostreidae) sebagai upaya pengelolaan berbasis 
struktur populasi di Kuala Gigieng, Aceh Besar. Tesis. Bogor (ID): Institut Pertanian Bogor.

Puspawati, N. N., Sugitha, I. M., Wisaniyasa, N. W., \& Suparthana, I. P. (2016). Introduksi Pengolahan Ubi Jalar Ungu (Ipomea batatas poiret) Menjadi Bakpia di Desa Negari Kecamatan Banjarangkan, 15, 229235.

Sujendran S, Senarath U \& Joseph J. (2015). Prevalence of Stunting among Children Aged 6 to 36 Months, in the Eastern Province of Sri Lanka. DOI: 10.4172/2161-0509.1000154.

Winarno, F.G. (1997). Pangan Gizi Teknologi dan konsumen. PT. Gramedia Pustaka Utama: Jakarta.

Winarno, F. G. (2004). Kimia Pangan dan Gizi. Jakarta: Gramedia Pengolahan. Universitas Gadja Mada. Yogyakarta.

Zilda, O., \& Sudiarti, T. (2013). Faktor Risiko Stunting pada Balita (24-59 Bulan) di Sumatera. Jurnal Gizi Dan Pangan, 8(3), 175-180. https://doi.org/10.25182/jgp.2013.8.3. 177-180 